\title{
ANALISIS SIKAP LINGKUNGAN DI MASYARAKAT KAWASAN PABRIK TAHU KABUPATEN MALANG
}

\author{
Purwaning Budi Lestari, Tri Asih Wahyu Hartati, Ardian Anjar Pangestuti \\ IKIP Budi Utomo \\ purwaning.budilestari@gmail.com, triasihibu@gmail.com, ardianpangestuti@gmail.com
}

\begin{abstract}
The purpose of this community service activity is to describe environmental attitudes in the community in the tofu factory area, Karangploso District, Malang Regency. The method of carrying out activities is through the survey method. Data analysis used descriptive statistics by looking at the percentage and average. The population used is residents around the tofu factory, Karangploso District, Malang Regency, with a sampling technique through accidental sampling. The instrument used is an attitude scale questionnaire, interviews. Based on the results of the description, the average environmental attitude indicator shows the following criteria: the 'High' criterion is indicated by the attitude indicator number $1,3,7,15$, then the 'Medium' criterion is indicated by the attitude indicator number 5,9,14, the 'Low' criterion is found. on the attitude indicator number 2,8,10,12,13, then the 'Very Low' criterion is indicated by the attitude indicator number 4 with an average of 1,7 . The conclusion of the environmental attitude of the community wants the need for an increase in waste management in the tofu factory area in Malang Regency.
\end{abstract}

Keywords: Public, tofu factory, environmental attitude

\section{ANALISIS SITUASI}

Keberadaan industri tahu di kecamatan Karangploso Kabupaten Malang, memunculkan reaksi di kalangan mayarakat terutama akibat limbah yang dihasilkan. Munculnya sikap peduli lingkungan sangat penting untuk pembangunan yang berkelanjutan. Pentingnya sikap lingkungan yang dapat digunakan sebagai alat ukur yang berguna untuk menentukan sikap masyarakat terhadap lingkungan (Arslan . 2012). Penelitian serupa oleh ( Crumpei et al. 2014) sikap lingkungan berperan penting dalam memprediksi perilaku ekologis, faktor-faktor lain sangat penting dalam memastikan transisi dari sikap ke tingkah laku. Setiap perubahan transformatif atau jangka panjang yang dihasilkan dari dimensi ekologi fenomena terbaik dapat diselidiki melalui sikap dan perilaku lingkungan, dimana sikap lingkungan meliputi kepedulian lingkungan dan hierarkinya dan sifat multidimensi (Voski, 2020). Adanya sikap peduli lingkungan harapannya dapat digunakan sebagai alat ukur seberapa tinggi sikap peduli lingkungan masyarakat di sekitar pabrik tahu di daerah Karangploso Malang.

Tahu adalah bagian dari masakan Asia dan mungkin merupakan makanan paling populer yang terbuat dari kedelai (Riciputi et al., 2016). Keberadaan industri tahu cukup potensial dalam penyerapan tenaga kerja yang dapat meningkatkan perekonomian masyarakat sekitar, namun di sisi lain juga dapat memberikan dampak negatif akibat air limbah yang dihasilkan dari proses pembuatan tahu yang berpotensi merusak lingkungan. Lokasi industri tahu tersebut menyatu dengan pemukiman penduduk, sehingga muncul permasalahan dengan warga sekitar.

Limbah tahu mengandung bahan organik yang tinggi, dikarenakan bahan baku pembuatan tahu (kedelai) mengandung protein hingga $40-60 \%$ ( Indah et al., 2014). Karakteristik buangan industri tahu meliputi dua hal, yaitu karakteristik fisika 
dan kimia. Karakteristik fisika meliputi padatan total, padatan tersuspensi, suhu, warna, dan bau. Karakteristik kimia meliputi bahan organik, bahan anorganik dan gas. Suhu air limbah tahu berkisar $37-45^{\circ} \mathrm{C}$, kekeruhan 535-585 FTU, warna 2.225-2.250 Pt.Co, amonia 23,3-23,5 mg/1, BOD5 6.000$8.000 \mathrm{mg} / 1$ dan COD 7.500-14.000 mg/1. Peraturan Menteri Lingkungan Hidup Nomor 15 Tahun 2008 tentang baku mutu air limbah bagi usaha dan atau kegiatan pengolahan kedelai bahwa usaha atau pengolahan kedelai berpotensi menimbulkan pencemaran dan kerusakan lingkungan hidup sehingga perlu dilakukan upaya pencegahan pencemaran air dengan menetapkan baku mutu air limbah baku mutu BOD yang ditetapkan yaitu $150 \mathrm{mg} / \mathrm{l}$. Sehingga perlu adanya pengolahan limbah terlebih dahulu sebelum di buang ke lingkungan (Nindra \& Hartini. 2015).

Berlokasi di Kecamatan Karangploso terdapat industri tahu kecil dan menengah. Karakteristik industri kecil dan menengah diantaranya penangan limbah yang kurang baik karena efisiensi pada penggunaan energi. Keadaan tersebut menyebabkan limbah akibat produksi tahu meningkat. Kandungan zat tersuspensi pada limbah cair tahu mengakibatkan air menjadi kotor, berbau hal ini akibat dari proses metabolisme bakteri pemecah sulfur pada limbah tahu. Penelitian oleh ( Masangkay. 2012) menyebutkan Performa tahu-whey sebagai media cair di perbanyakan mycobacterium tuberculosis strain H37Rv.

Selain menyebabkan polusi pada lingkungan perairan limbah cair tahu juga bermanfaat bagi masyarakat sekitarnya. Pemanfaatan limbah cair tahu sebagai pupuk organic selain dapat mengurangi dampak limbah juga dapat meningkatkan pendapatan masyarakat. Seperti penelitian oleh (Aliyenah et al. 2015) Pemanfaatan Limbah Cair Industri Tahu sebagai Pupuk Cair Organik terhadap Pertumbuhan dan Produksi Tanaman Kangkung Darat (Ipomoea reptans Poir). Manfaat lain dari limbah cair tahu adalah dapat digunakan sebagai pembuatan biogas Seperti penelitian oleh (Prayitno et al.2020)

Pentingnya analisis sikap lingkungan pada pengelolaan dan pemanfaatan limbah tahu karena berhubungan dengan perilaku lingkungan. Seperti penelitian (Liu et al., 2020) bahwa pengetahuan lingkungan berpengaruh positif signifikan terhadap sikap lingkungan, sikap lingkungan berpengaruh positif signifikan terhadap niat perilaku lingkungan dan perilaku pro lingkungan, dan niat perilaku lingkungan berpengaruh positif signifikan terhadap perilaku pro lingkungan. Analisis sikap peduli lingkungan diadaptasi dari (Ramlan \& Sumihardi, 2018) tentang pengelolaan dan penanganan limbah cair. indicator penanganan dan pengelahan limbah yang terdiri dari lima (5) indikator, antara lain: (1) Air limbah tidak boleh mencemari permukaan tanah; (2) Air limbah tidak boleh mengakibatkan sumber air bersih menjadi tercemar; (3) Air limbah tidak boleh mencemari air baku yang umumnya banyak digunakan untuk keperluan irigasi, perikanan, pembersihan dan lain sebagainya; (4) Air limbah tidak boleh menyebabkan pengotoran, yang mengganggu pemandangan dan menimbulkan bau busuk; dan (5) Air limbah bisa dikelola dengan prinsip Biologis

Berdasarkan latar belakang maka tujuan pengabdian ini adalah untuk mendeskripsikan sikap lingkungan di masyarakat di kawasan pabrik tahu Kabupaten Malang.

\section{METODE PELAKSANAAN}

Metode pelaksanaan pengabdian menggunakan metode survey dengan target/ mitra sasaran adalah masyarakat yang bertempat tinggal di sekitar pabrik tahu di Kabupaten Malang. Data diambil bulan September sampai bulan November 2021. Populasi adalah masyarakat yang tinggal di sekitar pabrik tahu kecamatan Karangploso Kabupten Malang. Pengambilan sampel dilakukan dengan accidental sampling. Jumlah sampel sebanyak 30 responden. 
Instrumen yang digunakan adalah rubrik skala sikap, wawancara, dan dokumentasi. Instrument sikap diadaptasi dari (Ramlan \& Sumihardi, 2018). Sedangkan skala likert diadaptasi dari (Ilmarinen et al., 2021a). Jumlah item pertanyaan untuk skala sikap sebanyak 15 pertanyaan. Dimana 15 kategori pertanyaan sikap lingkungan meliputi 8 pertanyaan positif dan 7 pertanyaan negatif. Pernyataan positif terdapat pada nomor $1,3,5,7,9,11,14$ dan 15 , sedangkan pernyataan negative terdapat pada nomor $2,4,6,8,10,12$,dan 13. Prosedur dimulai dari observasi di lokasi penelitian kemudian dilanjutkan dengan penetapan masalah dan pengambilan data melalui penyebaran rubrik sikap peduli lingkungan di masyarakat. Hasil survey dianalisis menggunakan statistic deskriptif kuantitatif untuk melihat persentase, rerata dan penetapan kriteria sikap peduli lingkungan. Persentase analisis sikap peduli lingkungan diadaptasi dari (Istiqomah, 2019).

\section{HASIL DAN PEMBAHASAN}

Hasil penelitian dideskripsikan rubrik analisis sikap peduli lingkungan pada pengelolaan dan pemanfaatan limbah cair tahu ditunjukkan pada gambar 1 dan tabel 1 . Hasil sikap peduli lingkungan yang terdapat pada gambar.1.

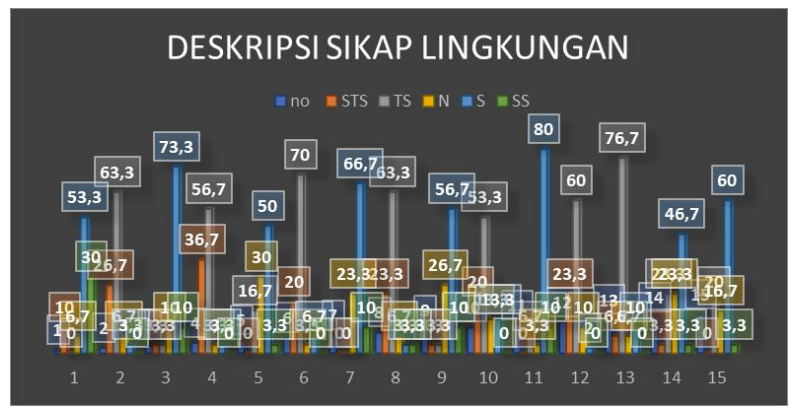

Gambar 1. Deskripsi Sikap Lingkungan

Selanjutnya secara terinci deskripsi sikap peduli lingkungan dalam persentase selanjutnya dijabarkan dalam tabel 1 berikut.

Tabel 1. Deskripsi Sikap Pengelolaan dan Pemanfaatan Limbah Tahu (dalam\%)

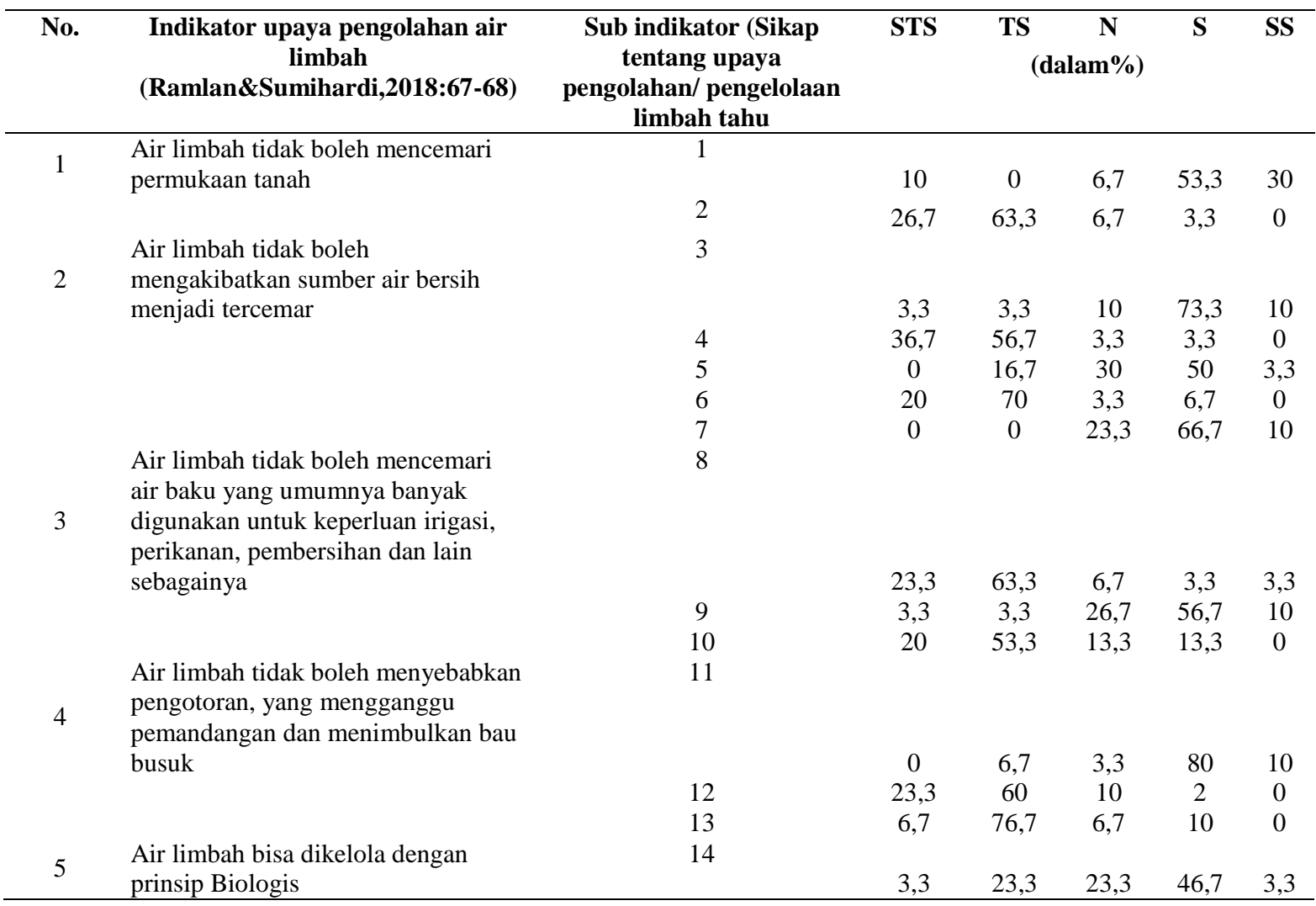


Keterangan:

Subindikator:

1. Perlu adanya pengelolaan limbah tahu dengan ramah lingkungan

2. Limbah tahu hasil sisa produksi mencemari lingkungan

3. Saya menetralisir limbah tahu sebelum dibuang sehingga air sungai tetap jernih dan tidak berbau

4. limbah cair tahu langsung dibuang ke sungai tanpa diolah terlebih dahulu

5. Perlu adanya edukasi tentang pengelolaan limbah tahu yang benar

6. Saya membuang limbah cair sehingga sungai menjadi kotor

7. Perlu adanya edukasi tentang pencemaran lingkungan akibat keberadaan limbah tahu

8. air limbah tahu menyebabkan biota di sungai terganggu

9. Menurut saya memanfaatkan limbah tahu sebelum dibuang sangat penting

10. tidak perlu ada pemanfaatan limbah sebelum dibuang

11. Sebagai pemilik tahu saya selalu mengolah limbah dengan baik

12. Sebagai Pemilik tahu saya tidak perlu memiliki bak penampungan limbah sebelum dibuang ke perairan

13. Sebagai pemilik pabrik tahu saya tidak perlu menjaga kebersihan lingkungan di sekitar pabrik tahu

14. Tidak sulit bagi saya untuk memanfaatkan limbah cair sebagai agen budidaya ikan

15. Perlu ada informasi tentang enceng gondok yang dapat menetralisir limbah

Selanjutnya rerata dan kriteria sikap ditunjukkan pada tabel 3.2 berikut. Berdasarkan tabel 3.2 terdapatlima (5) indikator upaya pengolahan air limbah yang

$\begin{array}{lccccc}15 & 0 & 20 & 16,7 & 60 & 3,3 \\ \text { digunakan } & \text { sebagai } & \text { sub } & \text { indikator } & \text { sikap } \\ \text { tentang upaya } & \text { pengolahan/pengelolaan } \\ \text { limbah tahu. } & & & & \end{array}$

Tabel 2. Rerata dan Kriteria Sikap

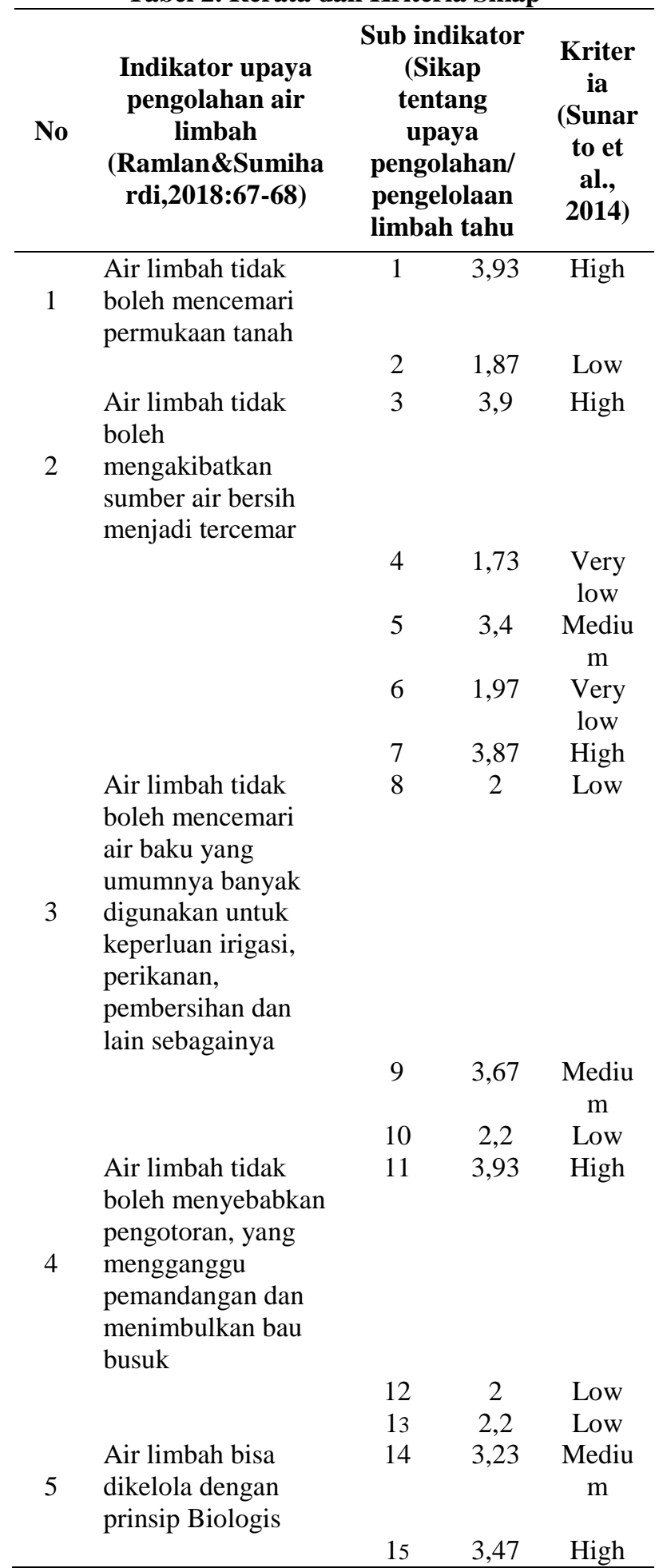


Berdasarkan hasil analisis sikap tentang upaya pengolahan dan pengelolaan limbah tahu menunjukkan bahwa pada indicator satu yaitu air limbah tidak boleh mencemari permukaan tanah dengan sub indicator "Perlu adanya pengelolaan limbah tahu dengan ramah lingkungan dengan rerata 3,9 dengan kriteria tinggi" dan "limbah sisa tahu mencemari lingkungan dengan rerata 1,8 dengan kriteria rendah". Berdasarkan hasil analisis sikap tersebut bahwa diperlukan pengolahan limbah agar tidak mencemari lingkungan. Indikator air limbah tidak boleh mengakibatkan sumber air bersih menjadi tercemar, didukung oleh indikator sikap "saya menetralisir limbah tahu sebelum dibuang sehingga air sungai tetap jernih dan tidak berbau sebesar 3,83 dengan kriteria tinggi". Hal ini mencerminkan bahwa masyarakat menghendaki pengelolaan limbah tahu dilakukan dengan baik. Jika pengelolaan limbah dilakukan dengan baik maka tidak akan mencemari lingkungan. Limbah tahu cenderung mencemari lingkungan perairan karena biomassa tipikal yang mengandung air tinggi (Tian et al., 2012).

Hasil analisis sikap menyimpulkan bahwa ketidaktahuan penanganan limbah banyak ditemukan dilokasi penelitian. Penanaman kesadaran pribadi terhadap lingkungan lokal ditemukan awal yang baik untuk menjaga kebersihan lingkungan (Brotosusilo \& Handayani, 2020). Sebuah penelitian meta-analisis determinan psikososial perilaku peduli lingkungan menemukan bahwa ada hubungan yang kuat antara atribusi internal, norma sosial dan perasaan rasa bersalah dan, yang paling penting, kesadaran dan pengetahuan tentang masalah lingkungan (Pavalache-Ilie \& Unianu, 2012). Sikap lingkungan dipengaruhi oleh beberapa hal, diantaranya pendidikan, usia dan pekerjaan. Penelitian oleh (Ilmarinen et al., 2021b) menyebutkan Analisis eksplorasi lebih lanjut menunjukkan bahwa sikap ini lebih terkait erat yang muda, yang lebih berpendidikan, dan di antara pemilih hak populasi yang paling ekstrim.
Hasil deskripsi sikap dengan indikator air limbah tidak boleh mencemari air baku yang umumnya banyak digunakan untuk keperluan irigasi, perikanan, pembersihan dan lain sebagainya dengan tiga sub indicator sikap yaitu "air limbah tahu menyebabkan biota di sungai terganggu rerata sebesar 4 dengan kriteria tinggi", menurut saya memanfaatkan limbah tahu sebelum dibuang sangat penting rerata 3,6 dengan kriteria tinggi. Berdasarkan hasil tersebut bahwa masyarakat menghendaki pemanfaatan limbah sebelum dibuang agar tidak mencemari lingkungan sehingga ekosistem tetap terjaga. Pentingnya sikap kesadaran akan lingkungan hidup karena juga berpengaruh terhadap keberlangsungan ekosistem yang ada di sekitar pabrik tahu. Menurut (Faccioli et al., 2020) menyatakan bahwa sikap peduli lingkungan berpengaruh terhadap ekosistem. Pendapat serupa oleh (Orellana-Ríos et al., 2017) tentang studi tentang sikap peduli lingkungan dan persepsi siswa sekolah yang terletak di kawasan lindung alam di Níjar Fields (Almería Spain). Perilaku lingkungan berkembang dari masa kanak-kanak hingga remaja awal dan mulai berkonsolidasi dari usia 10 tahun dan seterusnya, sedangkan sikap lingkungan tetap berubah setidaknya sampai awal masa dewasa (Otto et al., 2019). Oleh karena itu sangat penting menumbuhkan kesadaran bahwa alam berkontribusi terhadap kesejahteraan manusia. Begitu juga keberadaan limbah tahu, agar lingkungan sekitar tetap terjaga diperlukan sikap peduli pengelolaan dan pemanfaatan limbah tahu.

\section{KESIMPULAN}

Kesimpulan hasil analisis sikap menunjukkan bahwa sikap masyarakat terhadap upaya pengolahan dan pengelolaan limbah tahu untuk lima indikator adalah baik.

\section{Ucapan Terima Kasih}

Disampaikan kepada masyarakat sekitar pabrik tahu di Kecamatan Karangploso Kabupaten Malang atas 
bantuannya dalam pelaksanaan pengambilan data.

\section{DAFTAR PUSTAKA}

Aliyenah, A., Napoleon, A., \& Yudono, B. (2015). Pemanfaatan Limbah Cair Industri Tahu sebagai Pupuk Cair Organik terhadap Pertumbuhan dan Produksi Tanaman Kangkung Darat (Ipomoea Reptans Poir). Jurnal Penelitian Sains, 17(3), 168429.

Arslan, S. (2012). The Influence of Environment Education on Critical Thinking and Environmental Attitude. Procedia - Social and Behavioral Sciences, 55, 902-909. https://doi.org/10.1016/j.sbspro.2012.09 .579

Brotosusilo, A., \& Handayani, D. (2020). Dataset on waste management behaviors of urban citizens in large cities of Indonesia. Data in Brief, 32(32), 106053. https://doi.org/10.1016/j.dib.2020.10605 3

Crumpei, I., Boncu, S., \& Crumpei, G. (2014). Environmental Attitudes and Ecological Moral Reasoning in Romanian Students. Procedia - Social and Behavioral Sciences, 114, 461-465. https://doi.org/10.1016/j.sbspro.2013.12 .730

Faccioli, M., Czajkowski, M., Glenk, K., \& Martin-Ortega, J. (2020). Environmental attitudes and place identity as determinants of preferences for ecosystem services. Ecological Economics, 174(January), 106600. https://doi.org/10.1016/j.ecolecon.2020. 106600

Ilmarinen, V. J., Sortheix, F. M., \& Lönnqvist, J. E. (2021a). Consistency and variation in the associations between Refugee and environmental attitudes in European mass publics. Journal of Environmental Psychology, 73(November 2020). https://doi.org/10.1016/j.jenvp.2020.101
540

Ilmarinen, V. J., Sortheix, F. M., \& Lönnqvist, J. E. (2021b). Consistency and variation in the associations between Refugee and environmental attitudes in European mass publics. Journal of Environmental Psychology, 73(101540), $1-10$. https://doi.org/10.1016/j.jenvp.2020.101 540

Indah, L. sari, Hendrato, B., \& Soedarsono, P. (2014). KEMAMPUAN ECENG GONDOK (Eichhornia sp.), KANGKUNG AIR (Ipomea sp.), DAN KAYU APU (Pistia sp.) DALAM MENURUNKAN BAHAN ORGANIK LIMBAH INDUSTRI TAHU (SKALA LABORATORIUM). DIPONEGORO JOURNAL OF MAQUARES, 3(1), 1-6.

Istiqomah, I. (2019). Sikap Peduli Lingkungan Peserta Didik di MAN-1 Pekanbaru Sebagai Sekolah Adiwiyata. Dinamika Lingkungan Indonesia, 6(2), 95.

https://doi.org/10.31258/dli.6.2.p.95103

Liu, P., Teng, M., \& Han, C. (2020). How does environmental knowledge translate into pro-environmental behaviors?: The mediating role of environmental attitudes and behavioral intentions. Science of the Total Environment, 728 , 138126.

https://doi.org/10.1016/j.scitotenv.2020. 138126

Masangkay, F. R. (2012). The performance of tofu-whey as a liquid medium in the propagation of mycobacterium tuberculosis strain H37Rv. International Journal of Mycobacteriology, 1(1), 4550.

https://doi.org/10.1016/j.ijmyco.2012.01 .010

Nindra, D. Y., \& Hartini, E. (2015). Efektivitas tanaman teratai (Nympahea firecrest) dan eceng gondok (Eichhornia crassipes) dalam menurunkan kadar biochemical oxygen demand) pada 
limbah cair industri tahu. VISIKES: Jurnal Kesehatan Masyarakat, 14(2), 123-130.

https://publikasi.dinus.ac.id/index.php/v isikes/article/view/1197

Orellana-Ríos, A., Pozo-Llorente, M. T., \& Poza-Vilches, M. de F. (2017). Proenvironmental Attitudes and Teaching Practice in Secondary Schools Located in Natural Protected Areas from the Perception of Students: The Case of Níjar Fields (Almería -Spain). Procedia - Social and Behavioral Sciences, 237(June 2016), 1112-1118. https://doi.org/10.1016/j.sbspro.2017.02 .164

Otto, S., Evans, G. W., Moon, M. J., \& Kaiser, F. G. (2019). The development of children's environmental attitude and behavior. Global Environmental Change, 58(August 2018), 101947. https://doi.org/10.1016/j.gloenvcha.201 9.101947

Pavalache-Ilie, M., \& Unianu, E. M. (2012). Locus of control and the proenvironmental attitudes. Procedia Social and Behavioral Sciences, 33(2012), 198-202. https://doi.org/10.1016/j.sbspro.2012.01 .111

Prayitno, P., Rulianah, S., \& Nurmahdi, H. (2020). Pembuatan Biogas Dari Limbah Cair Tahu Menggunakan Bakteri Indigeneous. Jurnal Teknik Kimia Dan Lingkungan, 4(2), 90-95. https://doi.org/10.33795/jtkl.v4i2.141

Prayitno, Rulianah, S., \& Zamrudy, W. (2020). INDUSTRI TAHU DI SENTRA INDUSTRI TAHU TEGALPASANGAN - PAKIS MALANG Oleh : Juranl Abdimas, 7(2), 143-146.

Ramlan, J., \& Sumihardi. (2018). Sanitasi Industri Dan K3 (Edisi Tahu). Pusat pendidikan sumber Daya manusia Kesehatan, Kementerian Kesehatan Republik Indonesia.

Riciputi, Y., Serrazanetti, D. I., Verardo, V.,
Vannini, L., Caboni, M. F., \& Lanciotti, R. (2016). Effect of fermentation on the content of bioactive compounds in tofutype products. Journal of Functional Foods, 27, 131-139. https://doi.org/10.1016/j.jff.2016.08.041 Tian, Y., Kumabe, K., Matsumoto, K., Takeuchi, H., Xie, Y., \& Hasegawa, T. (2012). Hydrolysis behavior of tofu waste in hot compressed water. Biomass and Bioenergy, 39(39), 112-119. https://doi.org/10.1016/j.biombioe.2011. 12.031

Voski, A. (2020). The ecological significance of the overview effect: Environmental attitudes and behaviours in astronauts. Journal of Environmental Psychology, 70(January), 101454. https://doi.org/10.1016/j.jenvp.2020.101 454 